\title{
6-Thiocyanatoflavins and 6-Mercaptoflavins as Active-Site Probes of Flavoproteins ${ }^{\dagger}$
}

\author{
Vincent Massey* \\ Department of Biological Chemistry, University of Michigan, Ann Arbor, Michigan 48109 \\ Sandro Ghisla \\ Fakultät für Biologie, Universität Konstanz, D-7750 Konstanz, FRG \\ Kunio Yagi \\ Institute of Applied Biochemistry, Yagi Memorial Park, Mitake, Gifu 505-01, Japan
}

\begin{abstract}
Thiocyanatoflavins have been found to be susceptible to nucleophilic displacement reactions with sulfite and thiols, yielding respectively the 6-S-SO ${ }_{3}^{-}$-flavin and 6-mercaptoflavin, with rate constants at $\mathrm{pH} 7.0,20^{\circ} \mathrm{C}$, of $55 \mathrm{M}^{-1} \mathrm{~min}^{-1}$ for sulfite and $1000 \mathrm{M}^{-1} \mathrm{~min}^{-1}$ for dithiothreitol. The 6-SCN-flavin binds tightly to riboflavin-binding protein as the riboflavin derivative, to apoflavodoxin, apo-lactate oxidase, and apo-Old Yellow Enzyme as the FMN derivative, and to apo-D-amino acid oxidase as the FAD derivative. The riboflavin-binding protein derivative is inaccessible to dithiothreitol attack, and the lactate oxidase and D-amino acid oxidase derivatives show only limited accessibility. However, the flavodoxin and Old Yellow Enzyme derivatives react readily with dithiothreitol, indicating that the flavin 6-position is exposed to solvent in these proteins. The lactate oxidase and D-amino acid oxidase derivatives convert slowly but spontaneously to the 6-mercaptoflavin enzyme forms in the absence of any added thiol, indicating the presence of a thiol residue in the flavin binding site of these proteins. The reaction rates have been investigated of 6mercaptoflavins with iodoacetamide, $N$-ethylmaleimide, methyl methanethiolsulfonate, $\mathrm{H}_{2} \mathrm{O}_{2}$, and $m$ chloroperbenzoate, in both the free and protein-bound state. The results confirm the conclusions drawn from the studies with 6-SCN-flavins described above and from 6- $\mathrm{N}_{3}$-flavins [Massey, V., Ghisla, S., \& Yagi, K. (1986) Biochemistry (preceding paper in this issue)]. The spectral properties of the protein-bound 6-mercaptoflavin vary widely among the five proteins studied and show stabilization of the neutral flavin with flavodoxin and riboflavin-binding protein and of the anionic species by Old Yellow Enzyme, lactate oxidase, and D-amino acid oxidase. In the case of the latter two enzymes, the stabilization appears to be due to interaction of the negatively charged flavin with a positively charged protein residue located near the flavin pyrimidine ring. This positively charged residue appears to be responsible also for the strong stabilization of the two-electron oxidation state of the mercaptoflavin as the 6-S-oxide. With the other flavoproteins studied this oxidation level is stabilized as the 6-sulfenic acid or 6-sulfenate.
\end{abstract}

I $n$ the preceding papers we have described the preparation and properties of three flavins with reactive substituents at the flavin 6-position (Ghisla et al., 1986) and the reactions of one of these, 6-azidoflavin, bound to a series of flavoproteins (Massey et al., 1986). In the present paper we describe studies of these same flavoproteins in which the native flavin has been replaced by the other analogues, 6-thiocyanatoflavins and 6-mercaptoflavins. By virtue of their chemical reactivity these flavins promise to be very useful in providing information concerning the protein environment surrounding the flavin 6-position, a position of interest because of its proximity to the redox-active $\mathrm{N}(5)$ center.

\section{EXPERIMENTAL Procedures}

Materials. The flavin derivatives and apoproteins used were obtained as described previously (Ghisla et al., 1986). $\mathrm{NADP}^{+},{ }^{1} \mathrm{NADPH}$, glucose 6-phosphate, glucose-6-phosphate dehydrogenase, dithiothreitol, reduced glutathione, and yeast

\footnotetext{
${ }^{\dagger}$ This work was carried out partly while V.M. and S.G. were on sabbatical leave in Mitake and partly while V.M. continued his sabbatical leave in Konstanz. The work was supported in part by a grant from the Deutsche Forschungsgemeinschaft (Gh 2/4-4) to S.G., by grants from the U.S. Public Health Service (GM 11106), and by the Alexander von Humboldt Stiftung to V.M.
}

glutathione reductase were purchased from Sigma Chemical Co., St. Louis, and glutathione peroxidase was prepared from pig erythrocytes according to Yagi et al. (1980). Iodoacetamide and $N$-ethylmaleimide were purchased from Nakarai Chemicals, Kyoto, methyl methanethiolsulfonate was purchased from Aldrich, Milwaukee, and $m$-chloroperbenzoic acid was purchased from Tokyo Kasei Kogyo Co., Tokyo.

Methods. $m$-Chloroperbenzoic acid was made as a stock solution of approximately $0.1 \mathrm{M}$ by dissolving in analytical grade $\mathrm{CH}_{3} \mathrm{CN}$ and kept at $-20^{\circ} \mathrm{C}$ when not in use. For oxidative titrations of 6 -mercaptoflavins bound to apoproteins, an aliquot was diluted freshly $50-100$-fold in $\mathrm{CH}_{3} \mathrm{CN}$. The same dilution was standardized by titration into the coupled system of glutathione peroxidase and glutathione reductase, essentially as described by Pryor and Castle (1984). The standardization was carried out in $0.05 \mathrm{M}$ phosphate, $\mathrm{pH} 7.0$, $25^{\circ} \mathrm{C}$, with sufficient glutathione peroxidase and glutathione reductase to bring about the overall reaction within $1 \mathrm{~min}$. It

\footnotetext{
${ }^{1}$ Abbreviations: DTT, dithiothreitol; EDTA, ethylenediaminetetraacetic acid; FAD, flavin adenine dinucleotide; FMN, flavin mononucleotide; mcpb, $m$-chloroperbenzoate; $\mathrm{NADP}^{+}$, nicotinamide adenine dinucleotide phosphate; NADPH, reduced nicotinamide adenine dinucleotide phosphate; HPLC, high-performance liquid chromatography; NEM, $N$-ethylmaleimide; MMTS, methyl methanethiolsulfonate.
} 
was essential to include EDTA $(0.3 \mathrm{mM})$ to avoid high blank rates due to autoxidation of the reduced glutathione. The assay involves the coupled reactions

$$
\mathrm{ROOH}+2 \mathrm{GSH} \stackrel{\text { glutathione peroxidase }}{\longrightarrow} \mathrm{ROH}+\mathrm{GSSG}+\mathrm{H}_{2} \mathrm{O}
$$$$
\mathrm{GSSG}+\mathrm{NADPH}+\mathrm{H}^{+} \stackrel{\text { glutathione reductase }}{\longrightarrow}
$$$$
2 \mathrm{GSH}+\mathrm{NADP}^{+}
$$

and is followed by the oxidation of NADPH spectrophotometrically at $340 \mathrm{~nm}$.

The reactions of 6-SCN-flavins, free and protein bound, and the reactions of 6-mercaptoflavins, free and protein bound, were carried out in $0.05 \mathrm{M}$ phosphate, $\mathrm{pH} 7.0$, containing 0.3 mM EDTA, at $20^{\circ} \mathrm{C}$, and were monitored spectrophotometrically at wavelengths appropriate for the particular reaction, but mostly at 440 or $600 \mathrm{~nm}$. Details of individual experiments are given either in the text or in the legends to figures and tables.

Instrumentation. Absorption spectra were recorded with either a Shimadzu UV-250 spectrophotometer or a Kontron810 spectrophotometer, at $20^{\circ} \mathrm{C}$. HPLC analysis was done with a Shimadzu LC-4A instrument using a Develosil $(30 \times$ $0.7 \mathrm{~cm}) \mathrm{RP}_{18}$ column with an isocratic elution system of 30 parts methanol $/ 70$ parts $0.01 \mathrm{M}$ phosphate, $\mathrm{pH} 6.0$, at $40^{\circ} \mathrm{C}$.

\section{Results AND Discussion}

On the Mechanism of Conversion of 6-Thiocyanatoflavins to 6-Mercaptoflavins. In a previous study (Ghisla et al., 1980) it was shown that cyanide was eliminated from 6-SCN-flavins on photochemical reduction. The resulting 6-mercaptoflavin was quite susceptible to oxidation to the stable flavin-6-S-S6-flavin dimer, a property that seemed to preclude the use of 6-mercaptoflavins as active-site probes of flavoproteins. However, we have shown recently (Ghisla et al., 1986) that the conversion may be accomplished readily with a thiol such as dithiothreitol (DTT), which at the same time stabilizes the resulting 6-mercaptoflavin from oxidative dimerization and permits incorporation of the mercaptoflavin into apoproteins.

In view of the reactivity of 6-SCN-flavins with other nucleophiles and of flavoproteins reconstituted with this analogue at the FAD or FMN levels (cf. following sections), it became clear that also other mechanisms had to be considered for the formation of 6-mercaptoflavins. In particular, reaction with DTT may proceed not by a route involving flavin reduction but by $\mathrm{CN}^{-}$elimination through substitution, as illustrated in Scheme I. A major argument against reductive elimination of $\mathrm{CN}^{-}$comes from the lack of formation of 6-mercaptoflavin upon reduction with substrate of the 6-SCN-flavin bound to apo-Old Yellow Enzyme and apo-D-amino acid oxidase. On the other hand, evidence for a mechanism such as that shown in Scheme I came from studies where 6-SCN-flavins were reacted with DTT or mercaptoethanol. At high concentrations of these sulfhydryls, formation of 6-mercaptoflavin is fast and obeys pseudo-first-order kinetics, and the rate is directly dependent on the concentration of the sulfhydryl. No spectroscopic evidence for flavin reduction or formation of intermediates was observed. On the other hand, at low concentrations of sulfhydryls, there is a pronounced lag in the absorbance increase at either 440 or $600 \mathrm{~nm}$, the wavelengths useful for monitoring the production of 6-mercaptoflavin from $6-\mathrm{SCN}$ flavin [cf. Figure 2 and Ghisla et al. (1986)]. This lag is typical for autocatalytic processes and indicates that, under these conditions, a species is formed that affects the course of the reaction. A likely autocatalyst is 6-mercaptoflavin itself,

Scheme I
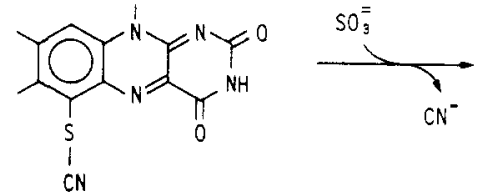

$\overbrace{\mathrm{CN}^{-}}$
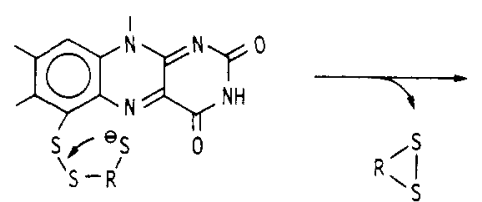

since it is present in its anionic form at neutral $\mathrm{pH}$ and thus should be a better nucleophile than either DTT or mercaptoethanol. Such a mechanism would require that reduction of flavin-6-S-S-R or the flavin-6-S-S dimer by DTT is faster than reaction with 6-SCN-flavin. This is indeed the case, as can be demonstrated experimentally with the flavin-6-S-S dimer.

A further complication is introduced by the effect of oxygen, which at air saturation and at low concentration of DTT enhances by approximately twofold the lag phase of formation of 6-mercaptoflavin, as compared with the corresponding anaerobic reaction. This observation can be rationalized by assuming that at low DTT concentrations reduction of the flavin indeed occurs and that it generates the autocatalytic species 6-mercaptoflavin by elimination of $\mathrm{CN}^{-}$. At the level of reduced 6-SCN-flavin a competition will occur between $\mathrm{CN}^{-}$ elimination and reoxidation by oxygen. Thus, depending on the specific conditions, the formation of 6-mercaptoflavins from 6-SCN-flavins might proceed by either of the mechanisms mentioned above or by a combination of them. In addition to these mechanisms radical processes cannot be excluded. Direct attack of a nucleophile at the 6-SCN function is in keeping with the reactivity with other nucleophiles such as sulfite described in the next section. That this is a major pathway is also consistent with the nearly stoichiometric formation of 6-mercaptoflavin when DTT in air-saturated solutions is used. This finding is inconsistent with a pathway in which flavin reduction is mandatory, since the latter would be expected to react rapidly with $\mathrm{O}_{2}$. Thus, once some 6mercaptoflavin is formed, it could act in an autocatalytic fashion by reaction with 6-SCN-flavin to generate the flavin-6-S-S dimer, which in turn is reduced very rapidly by DTT to produce the 6-mercaptoflavin.

Reaction of Sulfite with 6-SCN-flavins and with the Flavin-6-S-S-6-flavin Dimer. When 6-SCN-riboflavin is reacted with sulfite, there are small but distinct changes in the $a b-$ sorption spectrum, chiefly characterized by the development of a second absorption maximum at $375 \mathrm{~nm}$ and a considerable decrease in the fluorescence from that of the 6-SCN-flavin. In the HPLC isocratic elution system of $30 \%$ methanol $/ 70 \%$ $0.01 \mathrm{M}$ phosphate, $\mathrm{pH} 6.0,40^{\circ} \mathrm{C}$, the sulfite product has a retention time of $5.8 \mathrm{~min}$, compared to that of $10.9 \mathrm{~min}$ for 6-SCN-riboflavin, consistent with the introduction of a charged residue. The sulfite product is converted rapidly to $6-$ mercaptoriboflavin by addition of DTT. The spectral changes involved are shown in Figure 1, and the interpretation, in- 


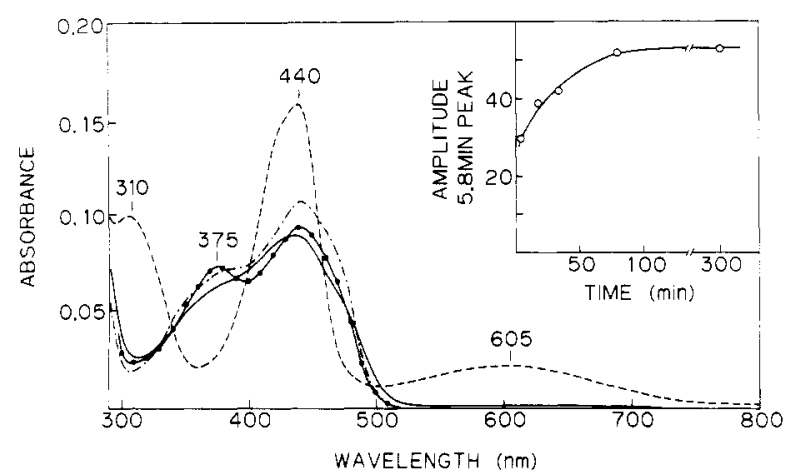

FIGURE 1: Spectra of 6-SCN-riboflavin and derivatives. (-.-) 6$\mathrm{SCN}$-riboflavin in $0.05 \mathrm{M}$ phosphate, $\mathrm{pH}$ 7.0. (๑) 6-S-SO ${ }_{3}^{-}$-riboflavin, formed from 6-SCN-riboflavin by reaction with $5 \mathrm{mM} \mathrm{Na}_{2} \mathrm{SO}_{3}$. (-) 6-S-S-flavin dimer, formed by reaction of 6-SCN-riboflavin with a 1.2-fold excess of dithiothreitol, shown after all the 600-nm absorbance had disappeared. (--) 6-mercaptoriboflavin, formed by addition of $0.5 \mathrm{mM}$ DTT to the 6-S-S-flavin dimer. The inset shows the time course of conversion of 6-S-S-riboflavin dimer to the 6-S-SO ${ }_{3}^{-}$form by addition of $10 \mathrm{mM} \mathrm{Na} \mathrm{SO}_{3}$ to an aerobic solution of the dimer, followed by HPLC analysis. Before addition of sulfite, there was no component eluting at $5.8 \mathrm{~min}$. The dimer has a retention time of 11.05 min; $>90 \%$ of it disappeared quickly on addition of sulfite. The same 5.8-min component was also obtained on incubation of 6-SCNriboflavin with sulfite (cf. Scheme I).

volving the formation of 6-S-SO ${ }_{3}^{-}$-riboflavin, is shown also in Scheme I. Figure 1 also illustrates the effect of addition of sulfite to the dimer formed by reacting 6-SCN-riboflavin with a slight excess of DTT and allowing the 6-mercaptoflavin to dimerize. In this case, in accord with the results previously described by Steenkamp et al. (1978), sulfite immediately returns half of the $A_{600}$ that could be obtained by addition of excess DTT to the dimer, followed by the slow disappearance again of the $600-\mathrm{nm}$ absorbance. This is readily explained by the sequence (Steenkamp et al., 1978)

step 1: flavin-6-S-S-6-flavin $+\mathrm{SO}_{3}{ }^{2-} \rightleftharpoons$

$$
\text { flavin-6-S-SO }{ }_{3}^{-}+\text {flavin-6-S }
$$

step 2: 2 flavin-6-S- $+\mathrm{O}_{2}+2 \mathrm{H}^{+} \rightarrow$

$$
\text { flavin-6-S-S-6-flavin }+\mathrm{H}_{2} \mathrm{O}_{2}
$$

step 3: repeat of step 1 at half the initial flavin

concentration, etc.

In this way all the dimer is finally converted to the flavin6-S- $\mathrm{SO}_{3}{ }^{-}$form, but with approximately half of the total formed in the first sulfitolysis step. Experimentally this was verified by following the formation of the riboflavin- $6-\mathrm{S}^{-} \mathrm{SO}_{3}{ }^{-}$by HPLC, as shown in the inset of Figure 1. Thus the same product is formed by direct sulfite reaction with $6-\mathrm{SCN}$ riboflavin or by sulfitoylsis of the disulfide dimer formed from 6-mercaptoriboflavin.

Reaction of 6-Mercaptoflavins with Common Thiol Reagents. The chemical reactivity of 6-mercaptoflavins, already documented by Steenkamp and co-workers (Steenkamp et al., 1978; Ghisla et al., 1980), and their $\mathrm{p} K$ of 5.9 (Ghisla et al., 1986) make them attractive candidates for active-site probes of flavoproteins. In order to assess the availability of the bound flavin to reaction by solvent-borne reagents, it is necessary to know the reaction rates of the free 6-mercaptoflavin with the reagent. In general, we have made all our comparative studies in $0.05 \mathrm{M}$ phosphate buffer, $\mathrm{pH} 7.0$, at $20^{\circ} \mathrm{C}$. Figure 2 illustrates the spectral changes occurring on reaction of 6-mercaptoriboflavin with iodoacetamide. As expected, the resulting 6-S- $\mathrm{CH}_{2} \mathrm{CONH}_{2}$-riboflavin has a spectrum similar to that of 6-SCN-riboflavin. The reaction course is that of a pseudo-first-order one, and the inset to

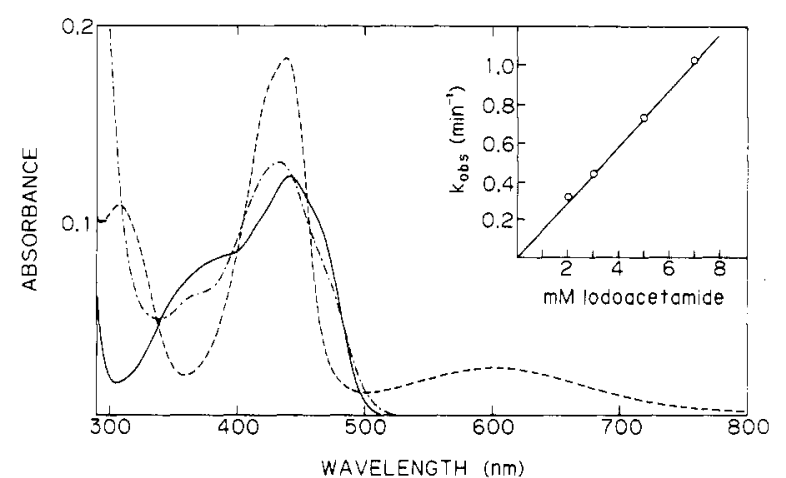

FIGURE 2: Spectra of 6-mercaptoriboflavin and its reaction product with iodoacetamide. (-) 6-SCN-riboflavin, in $0.05 \mathrm{M}$ phosphate, pH 7.0 , plus $0.3 \mathrm{mM}$ EDTA, $20^{\circ} \mathrm{C}$. (--) 6-Mercaptoriboflavin, formed by addition of $0.4 \mathrm{mM}$ dithiothreitol. (-.-) 6-S$\mathrm{CH}_{2} \mathrm{CONH}_{2}$-riboflavin, formed by reaction of the mercaptoflavin with $2 \mathrm{mM}$ iodoacetamide. The conversion was monitored at $440 \mathrm{~nm}$ and displayed pseudo-first-order kinetics. The inset shows the value of $k_{\text {obsd }}$ vs. iodoacetamide concentration, yielding the second-order rate constant of $150 \mathrm{M}^{-1} \mathrm{~min}^{-1}$.

Figure 2 shows a plot of the observed first-order rate vs. the iodoacetamide concentration. This yields a second-order rate constant of $150 \mathrm{M}^{-1} \mathrm{~min}^{-1}$ under these conditions (see also Table I).

Similar spectral changes are also given on reaction with methyl methanethiolsulfonate, a powerful thiol reagent introduced by Kenyon and co-workers (Smith et al., 1975). The reaction is very fast at $\mathrm{pH} 7$; in fact it was too fast to measure with a conventional spectrophotometer even at $\mathrm{pH} 5$, and at $\mathrm{pH} 4$ we could just measure the last $25 \%$ of the reaction. From this the rate constant at $\mathrm{pH} 4$ could be estimated as $4 \times 10^{4}$ $\mathrm{M}^{-1} \mathrm{~min}^{-1}$. The product of the reaction, 6-S-S- $\mathrm{CH}_{3}$-riboflavin, is reconverted rapidly to the starting 6-mercaptoflavin by addition of excess dithiothreitol.

Another reagent that reacts extremely rapidly with 6 mercaptoflavins is $N$-ethylmaleimide. As documented by Steenkamp et al. (1978), the reaction is accompanied by an almost complete loss of visible absorbance; the product appears to be a 5,6 cyclic adduct of the flavin. Again the reaction was too fast to measure at $\mathrm{pH} 7, \gg 4 \times 10^{4} \mathrm{M}^{-1} \mathrm{~min}^{-1}$ (Table I).

Peroxides also react readily with 6-mercaptoflavins, as has been found also with 8-mercaptoflavins (Moore et al., 1979), 2-thioflavins (Biemann et al., 1983), and 4-thioflavins (Massey et al., 1984). Unlike the reaction of 2- and 4-thioflavins, where flavin $S$-oxides are formed as intermediates on the way to the higher oxidation states of sulfinates and sulfonates, the principal product of reaction of $\mathrm{H}_{2} \mathrm{O}_{2}$ with free 6-mercaptoflavins is the flavin-6-S-S-6-flavin dimer, which is stable to further oxidation. This is readily recognized by its absorption spectrum (Figure 1), by its reconversion to 6-mercaptoflavin by dithiothreitol, and by HPLC (Table II). As we shall see in later sections, quite different reactions are found with 6mercaptoflavins bound to specific apoproteins.

6-SCN-flavins as Active-Site Probes. The conversion of 6-SCN-flavins to 6-mercaptoflavins by dithiothreitol offers a convenient way of probing the solvent accessibility to the flavin 6-position when bound to specific apoproteins. The results of such a study are summarized in Table I.

6-SCN-riboflavin binds very tightly $\left(K_{\mathrm{d}} \leq 10^{-8} \mathrm{M}\right)$ to riboflavin- (Rf) binding protein, with a shift in the $\lambda_{\max }$ from $441\left(\epsilon=13600 \mathrm{M}^{-1} \mathrm{~cm}^{-1}\right)$ to $454 \mathrm{~nm}\left(\epsilon=10300 \mathrm{M}^{-1} \mathrm{~cm}^{-1}\right)$ and a complete quenching of the flavin fluorescence. The resulting holoprotein reacts extremely slowly with dithiothreitol in a reaction that appears to be due to free 6-SCN-riboflavin in equilibrium with the protein-bound form; i.e., the observed 


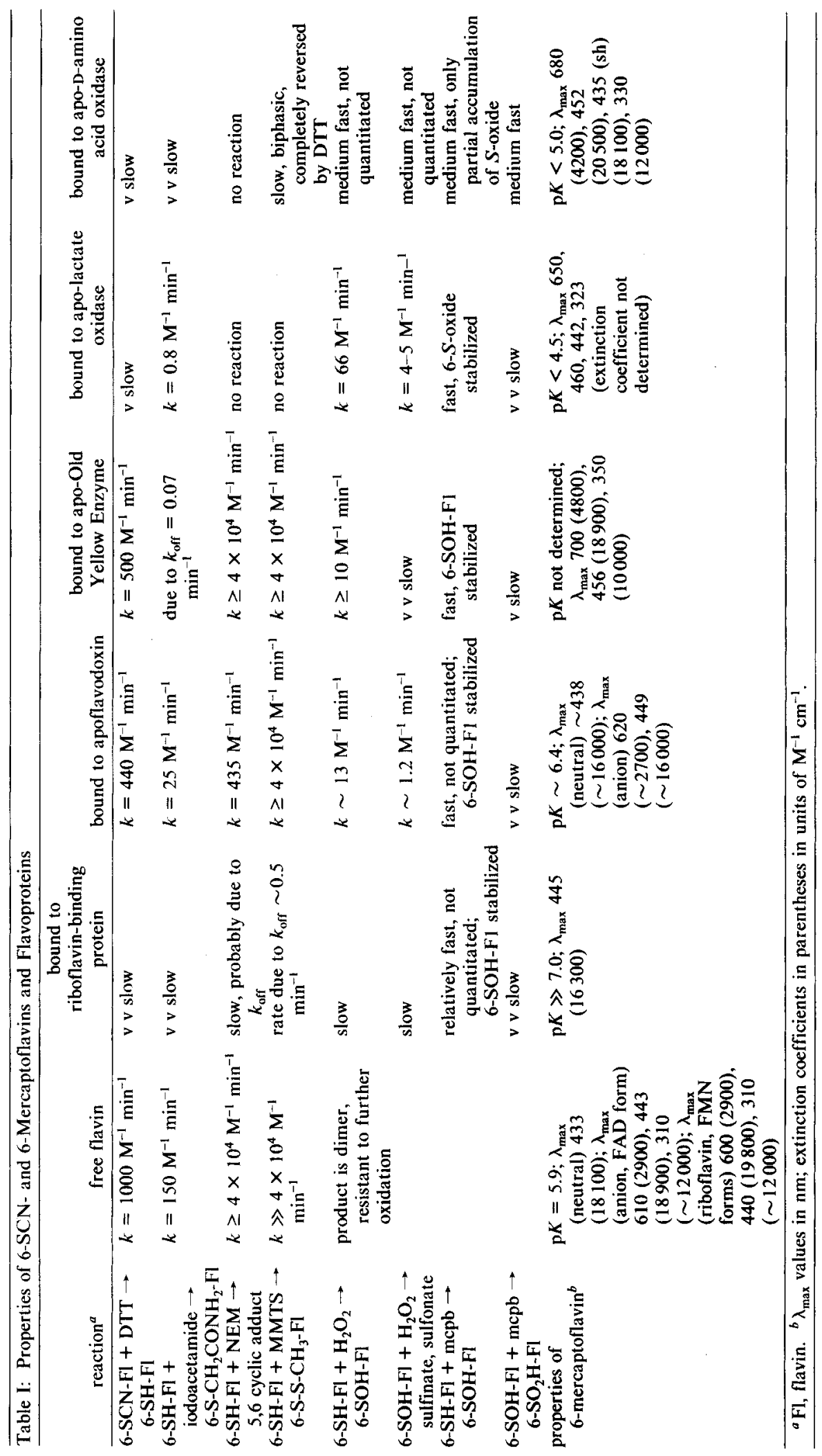




\begin{tabular}{|c|c|c|}
\hline flavin & retention time $(\mathrm{min})$ & fluorescence \\
\hline (solvent breakthrough) & $(3.0)$ & $(-)$ \\
\hline FAD & 3.95 & + \\
\hline FMN & 5.8 & + \\
\hline riboflavin & 11.0 & + \\
\hline 6-SCN-FAD & 4.15 & + \\
\hline 6-SCN-FMN & 5.7 & + \\
\hline 6-SCN-riboflavin & 10.9 & + \\
\hline 6-mercaptoriboflavin & 10.15 & - \\
\hline 6-S-S-riboflavin dimer & 11.05 & - \\
\hline $6-\mathrm{S}^{-\mathrm{SO}_{3}^{-}}-$-riboflavin & 5.8 & - \\
\hline $6-\mathrm{SO}_{3}^{-}$-riboflavin & 3.05 & + \\
\hline $6-\mathrm{SO}_{3}^{-}-\mathrm{FMN}$ & 2.55 & + \\
\hline
\end{tabular}

rate is determined by $k_{\text {off }}$ in eq 1 , with the overall reaction being described by eq $1-3$.

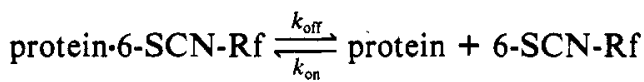

$$
\begin{aligned}
& \text { 6-SCN-Rf + DTT } \stackrel{k_{\mathrm{r}}}{\longrightarrow} 6-\mathrm{SH}-\mathrm{Rf}+\text { oxidized DTT }
\end{aligned}
$$

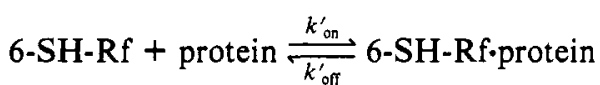

For example, when a mixture of $8 \mu \mathrm{M}$ 6-SCN-riboflavin and $15 \mu \mathrm{M}$ riboflavin-binding protein was reacted at $\mathrm{pH} 7.0$, $20^{\circ} \mathrm{C}$, with $5 \mathrm{mM}$ DTT, the spectrum changed to that of protein-bound 6-mercaptoriboflavin, with a $t_{1 / 2}$ of $140 \mathrm{~min}$. This should be compared with a $t_{1 / 2}$ of $8.3 \mathrm{~s}$ for the free flavin under the same conditions. From Schopfer et al. (1981) the $k_{\text {obsd }}$ value predicted from the above reactions is given by eq 4. With $k_{\mathrm{r}}$ known as $1 \times 10^{3} \mathrm{M}^{-1} \mathrm{~min}^{-1}$ (Table I) the $k_{\text {obsd }}$

$$
k_{\text {obsd }}=k_{\text {off }} k_{\mathrm{r}}[\mathrm{DTT}] /\left(k_{\text {on }}[\text { protein }]+k_{\mathrm{r}}[\mathrm{DTT}]\right)
$$

value of $5 \times 10^{-3} \mathrm{~min}^{-1}$ would be fitted by a value of $k_{\text {off }}$ of $0.5 \mathrm{~min}^{-1}$ and $k_{\text {on }}$ of $5 \times 10^{7} \mathrm{M}^{-1} \mathrm{~min}^{-1}$. These values are somewhat smaller than those determined by Becvar and Palmer (1982) for a series of flavins bound to riboflavinbinding protein but are consistent with the values obtained for binding of 6-mercaptoriboflavin (see later section). But, whatever the exact values of these constants, it is clear that the flavin is not exposed to solvent-borne reactant when it is bound to the protein, in good agreement with previous results with other flavins, which showed that only the pyrimidine ring of the bound flavin was accessible to solvent (Choi \& McCormick, 1980; Claiborne et al., 1982; Schopfer et al., 1981; Massey et al., 1984).

On the other hand, 6-SCN-FMN flavodoxin and 6-SCNFMN Old Yellow Enzyme react with dithiothreitol at rates approximately half that of the free flavin, in what are clearly second-order reactions (Table I). The flavin is bound tightly to apoflavodoxin $\left(K_{\mathrm{d}} \sim 5 \times 10^{-8} \mathrm{M}\right)$ with a shift of the $\lambda_{\max }$ from $441\left(\epsilon=13600 \mathrm{M}^{-1} \mathrm{~cm}^{-1}\right)$ to $447 \mathrm{~nm}\left(\epsilon=11300 \mathrm{M}^{-1}\right.$ $\left.\mathrm{cm}^{-1}\right)$. Binding to apo-Old Yellow Enzyme is less tight $\left(K_{\mathrm{d}}\right.$ $\left.\sim 5 \times 10^{-7} \mathrm{M}\right)$ with a shift in the $\lambda_{\max }$ to $451 \mathrm{~nm}(\epsilon=11400$ $\mathrm{M}^{-1} \mathrm{~cm}^{-1}$ ). In both cases, the observed rates of reaction with dithiothreitol are too fast to be consistent with the reaction occurring with dissociated flavin; in addition the rate is essentially independent of the apoprotein concentration present, a result not consistent with predictions from the dissociation mechanism of eq 4 . Hence it can be concluded that the flavin 6-position in both of these flavoproteins is available to attack by dithiothreitol.

While no information is available on the structure of Old Yellow Enzyme, the results with Megasphaera elsdenii flavodoxin are consistent with the known X-ray crystal structure of the related flavodoxin from Clostridium MP (Burnett et al., 1974; Smith et al., 1977). From that work it is known that

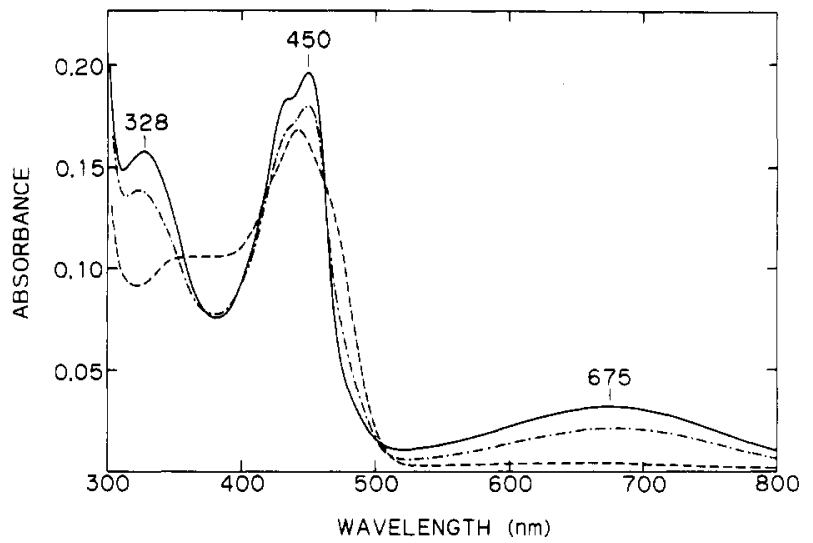

FIGURE 3: Spontaneous conversion of 6-SCN-FAD D-amino acid oxidase to the 6-mercapto-FAD enzyme. (---) Spectrum recorded $5 \mathrm{~min}$ after mixing $12.5 \mu \mathrm{M}$ 6-SCN-FAD with $17 \mu \mathrm{M}$ apo-D-amino acid oxidase in $0.02 \mathrm{M}$ pyrophosphate buffer, $\mathrm{pH} 8.5,20^{\circ} \mathrm{C}$. During this time there was a shift in $\lambda_{\max }$ from 446 to $442 \mathrm{~nm}$, indicating binding of the flavin to the apoenzyme. (-- ) Spectrum $21 \mathrm{~h}$ later. (-) Spectrum after $46 \mathrm{~h}$. The final product was shown to be identical with 6-mercapto-FAD enzyme, not only in its spectral properties but also in its kinetics of oxidation by $\mathrm{H}_{2} \mathrm{O}_{2}$ (cf. Figure 9).

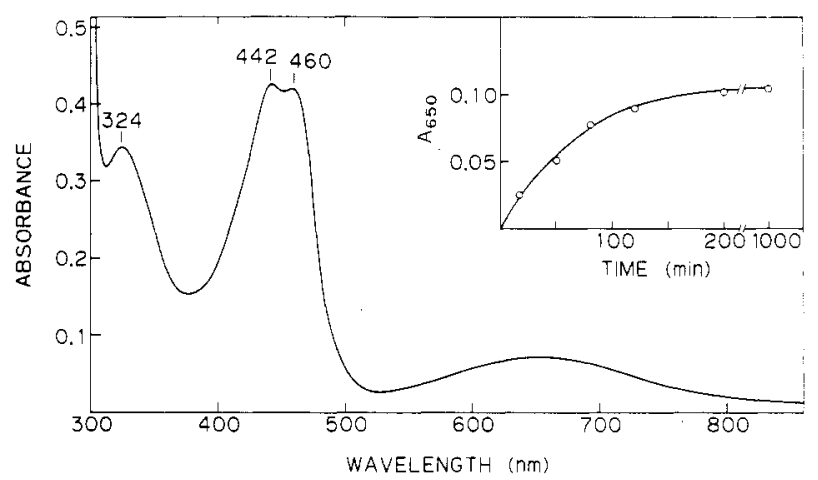

FIGURE 4: Spontaneous conversion of 6-SCN-FMN lactate oxidase to the 6-mercapto-FMN enzyme. Freshly prepared apoenzyme (Sullivan et al., 1977) $(\sim 100 \mathrm{nmol})$ was dissolved in $1 \mathrm{~mL}$ of $7 \times$ $10^{-5} \mathrm{M}$ 6-SCN-FMN in $0.05 \mathrm{M}$ phosphate, $\mathrm{pH} 7.0$, and centrifuged for $5 \mathrm{~min}$ at $10000 \mathrm{~g}$, and spectra were recorded at $20^{\circ} \mathrm{C}$ at intervals. The inset shows the time course of development of the $650-\mathrm{nm}$ band of 6-mercapto-FMN enzyme. The spectrum shown was obtained after overnight incubation, followed by dialysis for 2 days at $4{ }^{\circ} \mathrm{C}$ vs. 0.01 $\mathrm{M}$ imidazole, $\mathrm{pH}$ 7.0.

the flavin lies close to the protein surface, with the methyl groups at flavin positions 7 and 8 exposed to solvent. Although the figures in these publications give the impression that the flavin 6-position is shielded from solvent, examination of the structure by computer graphics reveals that the flavin 6 . position is accessible to solvent from a groove on the si side of the flavin. Furthermore, a substituent such as an azide or thiocyanate could be accommodated at this position without any distortion of the protein structure.

With lactate oxidase and D-amino acid oxidase it has not been possible to measure accurately the rates of reaction of the 6-SCN-flavins with dithiothreitol, although the rates are obviously slow, implying limited solvent accessibility. The reason why it is difficult to study this reaction is that in both cases the bound 6-SCN-flavin is converted spontaneously to the 6-mercaptoflavin without the addition of any exogenous thiol. The course of this reaction with 6-SCN-FAD D-amino acid oxidase is shown in Figure 3. The conversion is fairly slow, with a $t_{1 / 2}$ of approximately $10 \mathrm{~h}$ at $\mathrm{pH} 8.5,20^{\circ} \mathrm{C}$. The spectral properties and reactivity of the product are indistinguishable from those of enzyme reconstituted with authentic 6-mercapto-FAD (see later section). With 6-SCN-FMN bound to apo-lactate oxidase, the conversion is sufficiently 


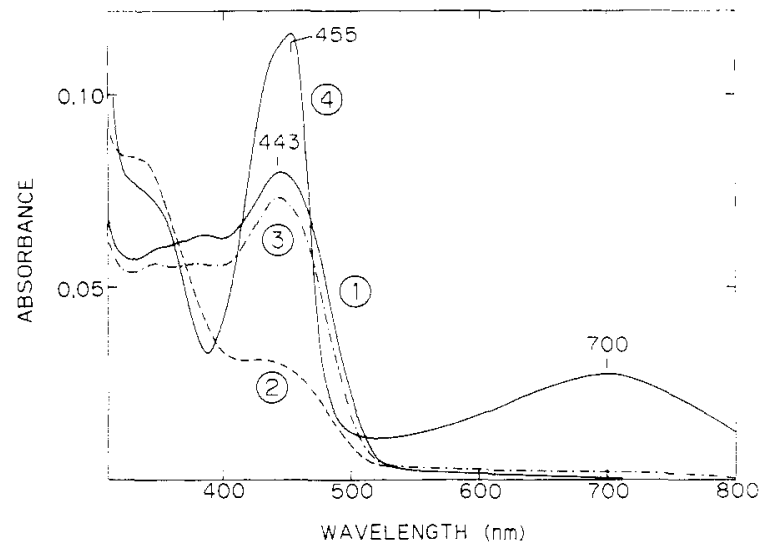

FIGURE 5: Lack of conversion of 6-SCN-FMN Old Yellow Enzyme to the 6-mercapto-FMN enzyme by reduction. Curve 1,6-SCN-FMN enzyme $(1 \mathrm{~mL})$ in $0.05 \mathrm{M}$ phosphate, $\mathrm{pH} 7.0,20^{\circ} \mathrm{C}$. Curve 2, spectrum obtained 30 min after the addition of $5 \mu \mathrm{M} \mathrm{NADPH}^{+}, 500$ $\mu \mathrm{M}$ glucose 6-phosphate, and $5 \mu \mathrm{L}$ of glucose-6-phosphate dehydrogenase. Curve 3 , spectrum obtained $60 \mathrm{~min}$ after addition, after mixing several times with air. Curve 4 , spectrum obtained after reaction of 6-SCN-FMN enzyme with $1 \mathrm{mM}$ dithiothreitol.

rapid that it is difficult to study properties of the 6-SCN-FMN enzyme. Figure 4 shows the spectrum of the 6-mercapto-FMN enzyme produced, and the inset shows the time course of the conversion at $\mathrm{pH} 7.0,20^{\circ} \mathrm{C}$, with a $t_{1 / 2}$ of approximately 1 h. Previous studies have indicated the presence of a protein thiol residue in the flavin binding sites of both these enzymes. Thus, with 4-thio-FMN bound to lactate oxidase there was a slow spontaneous conversion to normal FMN and formation of a protein persulfide (Massey et al., 1984). With D-amino acid oxidase, thiol reagents appear to exert an inhibitory effect by reaction with apoprotein and subsequent exclusion of the binding of FAD (Hellerman et al., 1965; Fonda \& Anderson, 1969). A plausible scheme for the spontaneous conversion of the 6-SCN-flavin enzymes to the 6-mercaptoflavin forms is as follows. In the first step, cyanide is eliminated by attack of an active-site thiolate. The resulting flavin-protein disulfide is then subjected to hydroxide ion attack to yield a protein sulfenic acid and the 6-mercaptoflavin anion. This reaction would be expected to be reasonably facile, since the $\mathrm{p} K$ of free 6-mercaptoflavin is 5.9 (Ghisla et al., 1986) and is lowered still further in enzymes such as lactate oxidase and D-amino acid oxidase, presumably by a positively charged protein residue in the vicinity of the flavin N(1)-position (Massey et al., 1969, 1979; Fitzpatrick \& Massey, 1983; this paper, later sections).

Effect of Substrate Reduction on 6-SCN-FMN Old Yellow Enzyme and 6-SCN-FAD D-Amino Acid Oxidase. Cyanide elimination from photochemically reduced 6-SCN-flavins has been demonstrated previously at low pH values (Ghisla et al., 1980 ) and confirmed at neutral $\mathrm{pH}$ in the present study (results not shown). In contrast, when 6-SCN-FMN is bound to apo-Old Yellow Enzyme and the aerobic solution treated with a NADPH-generating system, there is rapid reduction of the flavin (Figure 5). When the substrate of the generating system is exhausted through aerobic turnover, the original spectrum of the oxidized flavoprotein is recovered by $>90 \%$. Thus even though the enzyme-bound flavin remained reduced for more than $30 \mathrm{~min}$, there was practically no conversion to the 6-mercaptoflavin. For comparison, Figure 5 shows the spectrum of 6-SCN-FMN enzyme after reaction with dithiothreitol, where conversion to the 6-mercapto-FMN enzyme is rapid (cf. preceding section). A similar lack of conversion is found with 6-SCN-FAD D-amino acid oxidase on reduction with D-alanine (results not shown). These results support the conclusion reached in an earlier section that the main route of conversion of 6-SCN-flavins to 6-mercaptoflavins by DTT is by a direct nucleophilic displacement reaction rather than by $\mathrm{CN}^{-}$elimination from the reduced 6-SCN-flavin (cf Scheme I).

Binding of 6-Mercaptoflavins to Apoproteins. As documented previously (Steenkamp et al., 1978; Ghisla et al., 1986), the spectra of 6-mercaptoflavins are dependent on $\mathrm{pH}$, because of the $\mathrm{p} K$ of 5.9 of the thiol function. In analogy with 6-hydroxyflavins with a $\mathrm{pK}$ of 7.1 (Mayhew et al., 1974), 8-hydroxyflavins with a $\mathrm{p} K$ of 4.8 (Ghisla \& Mayhew, 1976), and 8-mercaptoflavins with a $\mathrm{p} K$ of 3.8 (Moore et al., 1979), 6-mercaptoflavins should serve as probes of the electrostatic environment of the protein-bound flavin. In the first paper in this series (Ghisla et al., 1986) we showed the tight binding of 6-mercaptoriboflavin to riboflavin-binding protein, and stabilization of the neutral form; i.e., the $\mathrm{p} K$ was shifted to considerably more alkaline values, in agreement with previous studies with this protein that have shown a marked preference of the protein for binding neutral flavin molecules (Blankenhorn et al., 1975; Choi \& McCormick, 1980; Becvar \& Palmer, 1982; Massey et al., 1979; Massey, 1980).

Flavodoxin is also known to bind preferentially the neutral form of 6-hydroxy-FMN (Mayhew et al., 1974) and 8hydroxy-FMN (Ghisla \& Mayhew, 1976). It also binds tightly to 6-mercapto-FMN $\left(K_{\mathrm{d}}<10^{-8} \mathrm{M}\right.$ at pH 7.0), again stabilizing the neutral form, but with only a small increase in $\mathrm{p} K$ to $\sim 6.4$ (Table I).

In contrast, the remaining apoproteins studied clearly stabilize the anion form of 6-mercaptoflavin, with a lowering of the $\mathrm{p} K$ to values that make it difficult or impossible to determine experimentally because of denaturation of the protein. Titration of 6-mercapto-FAD with apo-D-amino acid oxidase at $\mathrm{pH} 8.5,20^{\circ} \mathrm{C}$, gives a sharp end point, indicating that binding is very tight $\left(K_{d}<10^{-8} \mathrm{M}\right)$. The spectral properties are listed in Table I and are also shown in Figure 9. The same highly resolved spectrum is found at $\mathrm{pH} 5.5$, the lowest $\mathrm{pH}$ that could be used without denaturation of the protein. The 6-mercapto-FAD enzyme is not reduced even on prolonged incubation with $D$-alanine, a property shared with the 6hydroxy- (Mayhew et al., 1974), 8-hydroxy- (Ghisla \& Mayhew, 1976), and 8-mercapto-FAD enzymes (Massey et al., 1979). This lack of reactivity has been postulated to be due to the importance in normal catalysis of an enzyme base located close to the flavin N(1)-position, which is now involved in stabilization of the benzoquinoid form of the mercaptoflavin anion [cf. Massey and Ghisla (1983)]. The spectral properties of the tightly bound anionic form of 6-mercapto-FMN bound to lactate oxidase and Old Yellow Enzyme are summarized in Table $I$ and are also illustrated in Figures 4 and 6.

Reactions of 6-Mercaptoflavoproteins with Iodoacetamide, Methyl Methanethiolsulfonate, and N-Ethylmaleimide. The results of studies with five representative flavoproteins are summarized in Table I, and the type of spectral changes involved are illustrated in Figure 6 in the case of 6-SCN-FMN Old Yellow Enzyme.

With 6-mercaptoriboflavin bound to riboflavin-binding protein, all reactions are very slow and are probably due to the reaction with the small amount of free flavin in equilibrium with the protein-bound flavin (cf. eq 1-4). This is certainly the case with the very reactive compound, methyl methanethiolsulfonate, which reacts with free 6-mercaptoriboflavin extremely rapidly ( $k \gg 4 \times 10^{4} \mathrm{M}^{-1} \min ^{-1}$ at $\mathrm{pH} 7.0$ ). With the flavin in complex with riboflavin-binding protein $\left(K_{d}<\right.$ $10^{-8} \mathrm{M}$; Ghisla et al., 1986), the rate is almost independent 


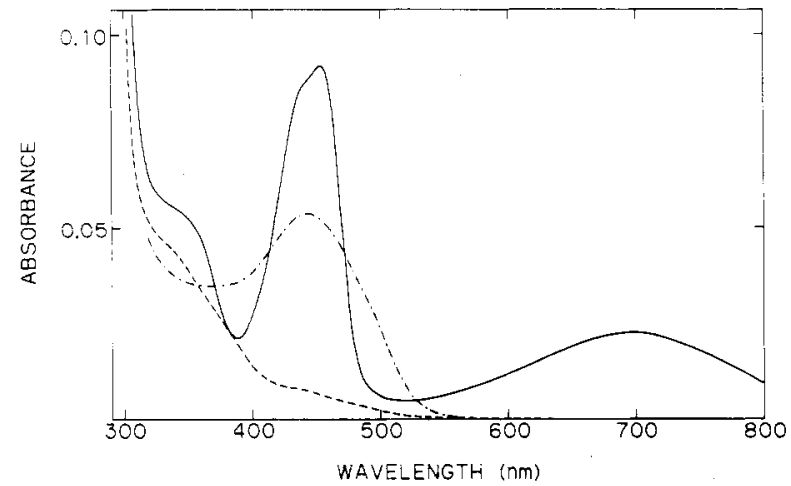

FIGURE 6: Spectra of 6-mercapto-FMN Old Yellow Enzyme and reaction products. (-) 6-Mercapto-FMN enzyme in $0.05 \mathrm{M}$ phosphate, $\mathrm{pH} 7.0,20^{\circ} \mathrm{C}$. (-.-) Spectrum obtained immediately after mixing with $0.6 \mathrm{mM}$ methyl methanethiolsulfonate. The resulting 6-S-S- $\mathrm{CH}_{3}-\mathrm{FMN}$ enzyme was rapidly reconverted quantitatively to the 6-mercapto-FMN enzyme on addition of excess DTT. (--) In a separate experiment, 6-mercapto-FMN enzyme was mixed with 0.3 $\mathrm{mM} N$-ethylmaleimide; the spectrum shown was obtained immediately after mixing.

of reagent concentration, varying from $0.31 \mathrm{~min}^{-1}$ at $1.2 \mathrm{mM}$ reagent concentration to $0.36 \mathrm{~min}^{-1}$ at $2.4 \mathrm{mM}$. This is consistent only with the situation where the reaction is with the free flavin, and the rate-limiting step is determined by the value of $k_{\text {off }}$ in eq 4, i.e., $k_{\text {off }} \approx 0.5 \mathrm{~min}^{-1}$. The 6-S-S-CH -riboflavin produced in the reaction then rebinds to riboflavin-binding protein, since centrifuging through an Amicon Centricon 10 ultrafiltration membrane results in less than $10 \%$ loss of the flavin into the ultrafiltrate. The observed rates with iodoacetamide and $N$-ethylmaleimide are also consistent with a $k_{\text {off }}$ value of $\sim 0.5 \mathrm{~min}^{-1}$ and the known values of $k_{\mathrm{r}}$, where $k_{\mathrm{r}}$ is the second-order rate constant for the reaction between free flavin and reagent (cf. eq 4).

With 6-mercapto-FMN flavodoxin, the reaction with iodoacetamide of $25 \mathrm{M}^{-1} \mathrm{~min}^{-1}$ is one-sixth that with free flavin, again implying reasonably good accessibility of the reagent to the flavin 6-position, similar to the conclusion reached for dithiothreitol reacting with the 6-SCN-FMN protein. The reaction with $N$-ethylmaleimide is moderately fast, although obviously a lot slower than that of the free reactants. This, however, is not surprising considering the complexity of the reaction and the considerable size of the substituent introduced (Steenkamp et al., 1978). The disappearance of the absorbance at $440 \mathrm{~nm}$ was exponential; thus no evidence for any intermediates was obtained. The reaction with methyl methanethiolsulfonate was very fast, being complete before the first reading could be made after mixing the reactants. The product was reduced rapidly to the starting 6-mercapto-FMN flavodoxin on addition of excess dithiothreitol. Together these results indicate strongly that, with both 6-SCN-FMN and 6-mercapto-FMN bound to apoflavodoxin, the flavin 6-position is readily accessible to solvent.

The spectral changes occurring with 6-mercapto-FMN Old Yellow Enzyme on reacting with $N$-ethylmaleimide and methyl methanethiolsulfonate are shown in Figure 6. In both cases the rates were too fast to measure with the apparatus available and again imply ready accessibility of the flavin 6-position. The 6-S-SCH 3 -FMN enzyme is rapidly reduced on addition of excess dithiothreitol, with quantitative return of the initial spectrum of 6-mercapto-FMN enzyme. In contrast to these rapid reactions, the reaction with iodoacetamide is surprisingly slow and appears to be due to reaction with free flavin (i.e., it is limited by $k_{\text {off }}$ ) since the observed rate of $0.1 \mathrm{~min}^{-1}$ is independent of reagent concentration. However, the resulting
6-S- $\mathrm{CH}_{2} \mathrm{CONH}_{2}-\mathrm{FMN}$ rebinds to the apoprotein, since on centrifuging the reaction mixture through a Centricon 10 ultrafiltration membrane for $90 \mathrm{~min}, 70 \%$ of the flavin remains associated with the protein. The enzyme-bound flavin is also reduced completely by addition of $\mathrm{NADP}^{+}$, glucose 6-phosphate and glucose-6-phosphate dehydrogenase. It is unclear to us why the enzyme-bound 6-mercaptoflavin should be inaccessible to iodoacetamide but freely accessible to $N$-ethylmaleimide and methyl methanethiolsulfonate.

With 6-mercapto-FMN lactate oxidase, iodoacetamide was found to react at a rate constant of $0.8 \mathrm{M}^{-1} \mathrm{~min}^{-1}$, almost 200 -fold slower than that of the free reagents, indicating a rather shielded flavin 6-position. This conclusion is borne out by the failure of both $N$-ethylmaleimide and methyl methanethiolsulfonate to result in any significant spectral changes. Similar lack of reactivity was found with 6-mercapto-FAD D-amino acid oxidase, where no significant reaction was found with iodoacetamide or $N$-ethylmaleimide and a slow biphasic reaction with methyl methanethiolsulfonate. With the latter, the spectrum of the original 6-mercapto-FAD enzyme was also returned quantitatively but slowly on addition of excess dithiothreitol.

Reaction of 6-Mercaptoflavins and 6-Mercaptoflavoproteins with Peroxides. While free mercaptoflavins are oxidized by peroxides predominantly to the stable dimer (see previous section), such a reaction is intrinsically unlikely for a protein-bound 6-mercaptoflavin, where the proper juxtaposition of two flavin molecules for flavin dimer formation would be very unlikely. In keeping with this expectation, we have not found any evidence for dimer formation with 6-mercaptoflavoproteins; instead, evidence was found for ready oxidation to the 6-sulfenate state, followed by still further oxidation, presumably to the sulfinate and sulfonate states.

With 6-mercaptoriboflavin bound to riboflavin-binding protein, the addition of $45 \mathrm{mM} \mathrm{H}_{2} \mathrm{O}_{2}$ resulted in the slow decrease of the absorbance at $440 \mathrm{~nm}\left(t_{1 / 2}\right.$ of $6 \mathrm{~min}$ at $\mathrm{pH} 7.0$, $\left.20^{\circ} \mathrm{C}\right)$ and a biphasic increase in absorbance at $360 \mathrm{~nm}\left(t_{1 / 2}\right.$ values of 5 and $20 \mathrm{~min}$ ). In the slow phase of the reaction a bright green fluorescence developed; on ultrafiltration through a Centricon 10 membrane approximately $40 \%$ of the $A_{440}$ remained with the protein, which was nonfluorescent, and $60 \%$ was found in the ultrafiltrate. This fraction was highly fluorescent and had absorption maxima at 438 and $360 \mathrm{~nm}$. It probably contains riboflavin-6-sulfinate or -sulfonate, consistent with the finding that riboflavin-binding protein binds negatively charged flavins only weakly or not at all.

When the 6-mercaptoriboflavin-binding protein was reacted with $0.4 \mathrm{mM} m$-chloroperbenzoate, there was a fairly rapid decrease $\left(t_{1 / 2}\right.$ of $\left.1 \mathrm{~min}\right)$ in absorbance $\left(\epsilon_{445}=16300 \mathrm{M}^{-1} \mathrm{~cm}^{-1}\right)$. Over a further $2 \mathrm{~h}$ there was very little further change in spectrum and the reaction mixture had no visible fluorescence. On addition of $3 \mathrm{mM}$ dithiothreitol, the initial spectrum of the 6-mercaptoriboflavin bound to the protein was restored, but very slowly, with a $t_{1 / 2}$ of $\sim 25 \mathrm{~min}$. These results imply that $m$-chloroperbenzoate can oxidize the protein-bound mercaptoflavin to the 6-sulfenate but, unlike $\mathrm{H}_{2} \mathrm{O}_{2}$, is not capable of further oxidation. Consistent with this interpretation is the fact that dithiothreitol can reduce the oxidation product back to 6-mercaptoriboflavin. The product cannot be the flavin-6-S-S-6-flavin dimer free in solution, because the free dimer is converted rapidly ( $t_{1 / 2}$ of seconds) back to 6-mercaptoriboflavin with $3 \mathrm{mM}$ dithiothreitol. Thus, the oxidation product is protein bound.

6-Mercapto-FMN flavodoxin reacts relatively fast with $m$-chloroperbenzoate, requiring the addition of approximately 


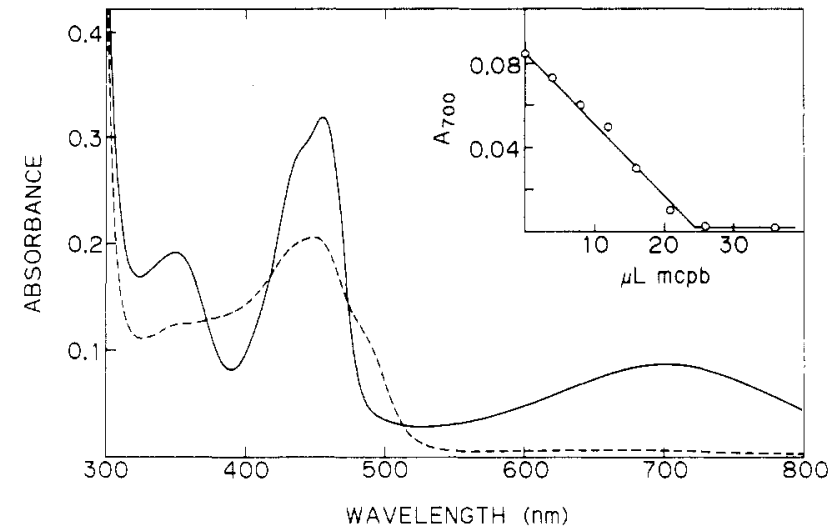

FIGURE 7: Titration of 6-mercapto-FMN Old Yellow Enzyme with $m$-chloroperbenzoic acid. The 6-mercapto-FMN enzyme was prepared by incubation of 6-mercapto-FMN with a slight excess of apoprotein, followed by gel filtration on Sephadex G-25 equilibrated with 0.05 $M$ phosphate, $\mathrm{pH}$ 7.0. The enzyme fractions were then concentrated by ultrafiltration by centrifuging through a Centricon 10 membrane. A $1.0-\mathrm{mL}$ sample of enzyme $(16.9 \mu \mathrm{M})$ (solid curve) was then titrated with an $860 \mu \mathrm{M}$ solution of $m$-chioroperbenzoic acid dissolved in $\mathrm{CH}_{3} \mathrm{CN}$. The titration proceeded with isosbestic points at 369,418 , 472 , and $519 \mathrm{~nm}$ to yield the spectrum shown by the dashed curve. The inset shows the $A_{700}$ vs. the amount of mcpb added, giving an end point for the oxidation of $1.3 \mathrm{~mol}$ of $\mathrm{mcpb} / \mathrm{mol}$ of enzyme-bound flavin. The spectrum of the initial 6-mercapto-FMN form was regenerated rapidly on the addition of 1 mM DTT.

an equimolar equivalent for the loss of the long-wavelength absorbance of the mercaptoflavin and, therefore, presumably forming the flavin-6-sulfenate. Addition of a further 3 equiv does not cause any immediate changes in the spectrum, but overnight incubation leads to the appearance of a second absorption band with a $\lambda_{\max }$ of $379 \mathrm{~nm}$ and a further decrease in the absorption at $445 \mathrm{~nm}$. At $\mathrm{pH} 7.0$, the extinction coefficients and $\lambda_{\max }$ of the main absorption band were as follows: before additions, $\epsilon_{445}=16000 \mathrm{M}^{-1} \mathrm{~cm}^{-1}$; two-electron oxidation state, $\epsilon_{440}=14300 \mathrm{M}^{-1} \mathrm{~cm}^{-1}$; after further oxidation, $\epsilon_{444}=11700 \mathrm{M}^{-1} \mathrm{~cm}^{-1}$. After overnight incubation the solution is still virtually nonfluorescent, indicating that the flavin, presumably at the sulfinate or sulfonate oxidation level, is still protein bound. The 6-mercaptoflavoprotein undergoes similar biphasic spectral changes with $\mathrm{H}_{2} \mathrm{O}_{2}$, the long-wavelength absorption disappearing with a rate constant of $13 \mathrm{M}^{-1} \mathrm{~min}^{-1}$ at $\mathrm{pH} 7.0,20^{\circ} \mathrm{C}$, and the near-UV band at $379 \mathrm{~nm}$ appearing with a rate constant of $1.2 \mathrm{M}^{-1} \mathrm{~min}^{-1}$. The results with $\mathrm{H}_{2} \mathrm{O}_{2}$ are complicated, however, by the gradual appearance of fluorescence and the loss of flavin binding by the protein, presumably due to oxidation of a protein thiolate known to be required in the intact state for flavin binding to the apoprotein (Mayhew, 1971).

The results of reaction of 6-mercapto-FMN Old Yellow Enzyme with peroxides are illustrated in Figure 7. The dashed spectrum is that obtained on titration of the enzyme with $m$-chlorobenzoate (inset); the identical spectrum is obtained on reaction with $\mathrm{H}_{2} \mathrm{O}_{2}$. The equivalence point shown in the inset corresponds to the addition of 1.3 equiv of peracid for the complete disappearance of the long-wavelength absorption. The extinction coefficient of the enzyme-bound flavin is decreased from $\epsilon_{456}=18900 \mathrm{M}^{-1} \mathrm{~cm}^{-1}$ to $\epsilon_{448}=12500 \mathrm{M}^{-1} \mathrm{~cm}^{-1}$. The primary oxidation product must be the flavin-6-sulfenate (6-SOH-flavin) on the basis of the titration with $m$-chloroperbenzoate. This species is, however, surprisingly resistant to further oxidation. Extended incubation with $\mathrm{H}_{2} \mathrm{O}_{2}$ or excess peracid is required for further oxidation. Consistent with the known properties of flavinsulfenates (Biemann et al., 1983; Massey et al., 1984), the primary oxidaticn product is rapidly

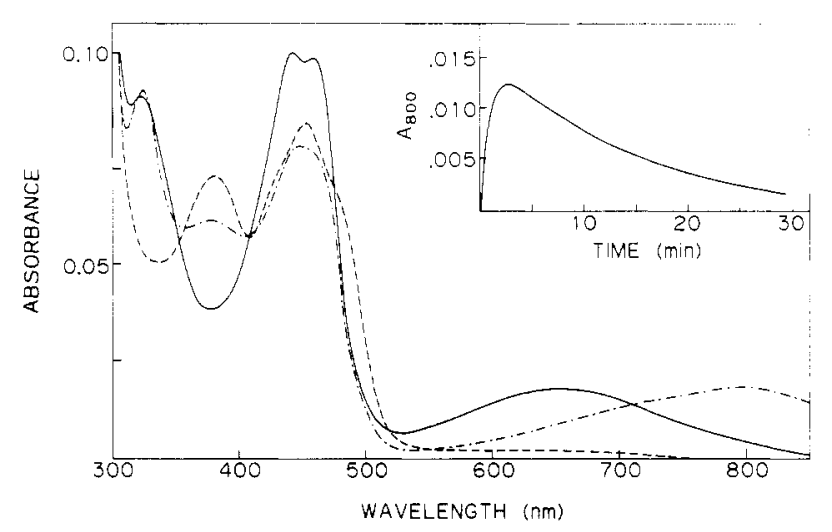

FIGURE 8: Effect of $\mathrm{H}_{2} \mathrm{O}_{2}$ and $m$-chloroperbenzoic acid on 6mercapto-FMN lactate oxidase. (-) Dialyzed 6-mercapto-FMN lactate oxidase in $0.01 \mathrm{M}$ imidazole buffer, $\mathrm{pH}$ 7.0. (-.-) Spectrum obtained after titration with mcpb. From the changes in $A_{440}$ and $A_{800}, 5.8 \pm 0.2 \mu \mathrm{M}$ mcpb was used to bring about the observed changes. Assuming an $\epsilon_{440}$ for the 6-mercapto-FMN enzyme of $19000 \mathrm{M}^{-1}$ $\mathrm{cm}^{-1}$, the enzyme concentration was $5.4 \mu \mathrm{M}$, yielding a value of $1.04-1.1 \mathrm{~mol}$ of $\mathrm{mcpb} / \mathrm{mol}$ of enzyme. Further oxidation by excess mcpb was an extremely slow process. (- $)$ Final spectrum obtained after reaction of 6-mercapto-FMN enzyme with $18 \mathrm{mM} \mathrm{H}_{2} \mathrm{O}_{2}$. The inset shows the time course of this reaction, followed at $800 \mathrm{~nm}$, showing the intermediate formation of the same oxidation product as formed with mcpb. Identical results were obtained with 6-SCNFMN enzyme, which was allowed to convert spontaneously to the 6-mercapto-FMN form (cf. Figure 4).

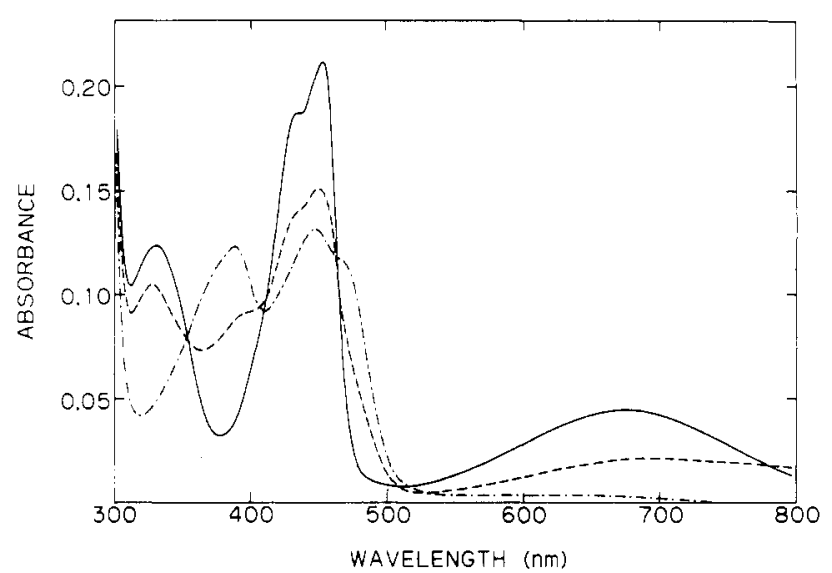

FIGURE 9: Titration of 6-mercapto-FAD D-amino acid oxidase with $m$-chloroperbenzoic acid. (-) 6-Mercapto-FAD enzyme, freed of excess DTT by $2 \times$ ultrafiltration through a Centricon 10 membrane and dissolved in $1.0 \mathrm{~mL}$ of $0.02 \mathrm{M}$ pyrophosphate, $\mathrm{pH} 8.5$. (--) Spectrum obtained after addition of 1.0 equiv of mcpb. (-.-) Spectrum obtained after addition of 2.0 equiv of mcpb.

and quantitatively rereduced to the 6-mercapto-FMN enzyme on addition of excess dithiothreitol. While the enzyme-bound sulfenate is resistant to further oxidation, it can be oxidized on release from the protein. When the oxidized enzyme was denatured with $5 \%$ trichloroacetic acid and centrifuged and the supernatant reneutralized, the spectrum was similar to that of known 6-SR-flavins, such as 6-SCN-FMN. At pH 7.0, 20 ${ }^{\circ} \mathrm{C}$, a two-banded spectrum $\left(\lambda_{\max } 370,440 \mathrm{~nm}\right)$ and a bright green fluorescence developed, with a $t_{1 / 2}$ of $5 \mathrm{~min}$, when 0.3 $\mathrm{mM}$ peracid was added to the neutralized supernatant. By HPLC the major product eluted in front of the solvent breakthrough (Table II).

In contrast to the results so far described, 6-mercapto-FMN lactate oxidase and 6-mercapto-FAD D-amino acid oxidase behave differently in the nature of the primary products of the oxidation (Figures 8 and 9). Figure 8 shows the results of several experiments with 6-mercapto-FMN lactate oxidase. Titration of the enzyme with $m$-chloroperbenzoate leads to the 
Scheme II

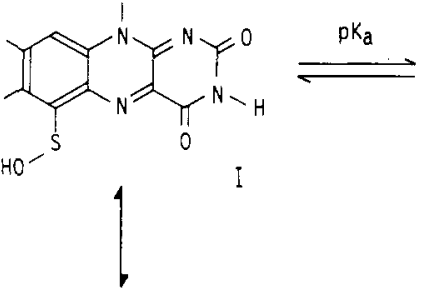<smiles>Cc1cc2c(=O)n(C)c3nc(=O)[nH]c(=O)c-3nc2c(C)c1CO</smiles><smiles></smiles>

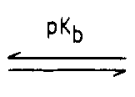

$\mathrm{HO}^{-}-\mathrm{S}_{\oplus}$
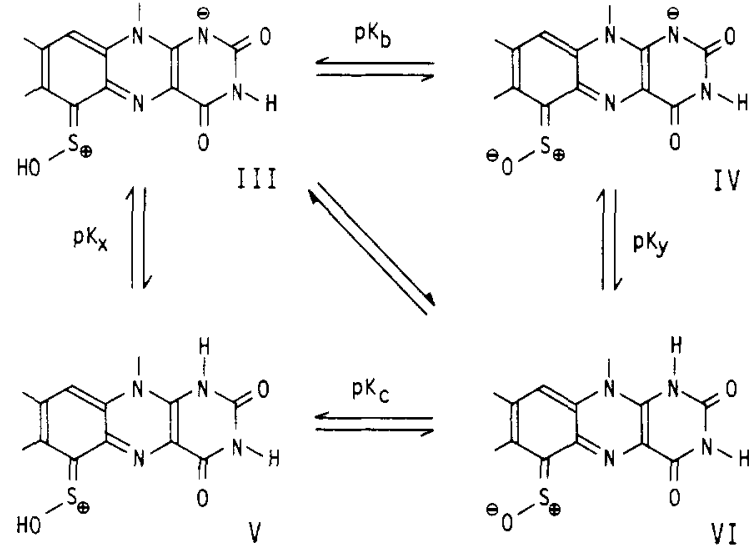

production of a new absorption band centered at $800 \mathrm{~nm}$, and with other $\lambda_{\max }$ at 448,380 , and $325 \mathrm{~nm}$. In this process, 1.0-1.1 equiv of peracid was consumed. Addition of a further equivalent of peracid had no effect on the spectrum over a period of $1 \mathrm{~h}$. The flavin is obviously at the oxidation level of the sulfenic acid, but the spectrum is quite different from that of the same oxidation level bound to Old Yellow Enzyme, where there is no long-wavelength absorbance. These properties indicate that with lactate oxidase the product is stabilized as the sulfoxide (Scheme II, form IV) while with Old Yellow Enzyme it is the sulfenate (Scheme II, form II) that is stabilized. Indeed there is good reason to believe that it is the anion form of the $S$-oxide that would be stabilized, because of a positively charged protein residue in the vicinity of the flavin $N(1)$-position, which stabilizes anionic flavin species, including the 6-mercaptoflavin anion (cf. earlier section).

While the flavin $S$-oxide bound to lactate oxidase is resistant to further attack by the peracid, $\mathrm{H}_{2} \mathrm{O}_{2}$ is able to carry the oxidation further. Figure 8 (inset) shows the time course of absorbance changes at $800 \mathrm{~nm}$ when 6-mercapto-FMN enzyme was reacted with $18 \mathrm{mM} \mathrm{H}_{2} \mathrm{O}_{2}$, and the dashed curve shows the spectrum of the final product, with a clear twobanded spectrum $\left(\lambda_{\max } 380,453 \mathrm{~nm}\right)$. Both phases of the reaction have rates directly proportional to the $\mathrm{H}_{2} \mathrm{O}_{2}$ concentration, with second-order rate constants of $66 \mathrm{M}^{-1} \mathrm{~min}^{-1}$ for the formation of the $S$-oxide and 4-5 $\mathrm{M}^{-1} \mathrm{~min}^{-1}$ for its further oxidation.

In the case of 6-mercapto-FAD D-amino acid oxidase, the flavin $S$-oxide is also formed on oxidation. With this enzyme, however, the $S$-oxide is susceptible to further oxidation by $m$-chloroperbenzoate. Figure 9 shows the spectra obtained after the addition of 1.0 and 2.0 equiv of percacid. The spectral changes after the addition of each aliquot of peracid take $\sim 10$ min to come to completion; hence it can be concluded that there is only limited accessibility to the flavin 6-position. While the spectrum after 1 equiv of peracid clearly indicates the presence of $S$-oxide, this spectrum also has contributions from the sulfinate and starting enzyme. This could be verified in a separate experiment where dithiotheitol was added after addition of 1 equiv of peracid. In that case there was ap- proximately $50 \%$ return of the initial spectrum of the mecaptoflavin enzyme. As only the $S$-oxide can be rereduced to the mercaptoflavin, it can be concluded that the rate of conversion to the $S$-oxide is approximately the same as the further oxidation of the $S$-oxide to the sulfinate. Exactly 2 equiv of peracid were required for full formation of the latter. As expected, dithiothreitol was not capable of rereducing the enzyme at this oxidation state. The oxidized enzyme spectrum is not bleached by $\mathrm{D}$-alanine, nor does it appear to bind benzoate. These properties are as expected for an enzyme flavin in which a negatively charged sulfinate or sulfonate residue is introduced, presumably in the vicinity of the enzyme base normally responsible for binding of substrate or benzoate.

Why should some enzymes stabilize the two-electron-oxidized mercaptoflavin as the $S$-oxide, while others appear to stabilize it as the sulfenate? For a discussion of this point it is necessary to consider the various tautomeric and mesomeric forms of the neutral and anionic forms. As shown in Scheme II, ionization may occur at either position 6 or position 1, with at least five microscopic $\mathrm{p} K$ values. Forms I and II would be expected to have absorption spectra similar to that of 6 SCN-flavins, while forms III-VI, with their benzoquinoid structure, would be expected to have long-wavelength absorption bands, similar to that shown by the anion form of 6-mercaptoflavin. In free solution, the flavin appears to exist predominantly as the sulfenate (forms I and II) since on release from Old Yellow Enzyme, the spectrum is virtually unchanged in shape from that of 6-SCN-FMN or the enzyme-bound oxidized flavin (cf. Figure 7). Hence it might be concluded that when bound to Old Yellow Enzyme, as well as to riboflavin-binding protein or to flavodoxin, the sulfenic acid, I, or the sulfenate, II, is the species stabilized. On the other hand, with lactate oxidase or with D-amino acid oxidase, one of the species III-VI must be stabilized by interaction with the protein. As already discussed [cf. Massey and Ghisla (1983) for a review], there is considerable evidence for the existence of a positively charged residue in the vicinity of the flavin $\mathrm{N}(1)$-position with these enzymes. Hence it is reasonable to expect that these enzymes would stabilize the sulfoxide species III or IV. With Old Yellow Enzyme, there is no compelling evidence for a positively charged residue near the flavin $\mathrm{N}$ (1)-position; in fact, the majority of the available evidence argues against it. For example, the native enzyme does not form an $N(5)$-sulfite adduct (Massey et al., 1969), nor does it stabilize the anion form of 8-hydroxy-FMN (Ghisla et al., 1976). While it does form a red semiquinone (presumably the anion) on photochemical reduction, this is because the semiquinone is more kinetically than thermodynamically stabilized (Stewart \& Massey, 1985). Furthermore, in contrast to D-amino acid oxidase (Van den Berghe-Snorek \& Stankovich, 1985) and lactate oxidase (Stankovich \& Fox, 1983) where the flavin redox potential is raised to considerably more positive values than that of free flavin, consistent with stabilization of the dihydroflavin anion by the protein and the consequent tighter binding of the reduced flavin to the protein than of the oxidized flavin, with Old Yellow Enzyme the redox potential of enzyme-bound FMN is more negative than that of free FMN (Stewart \& Massey, 1985); i.e., oxidized FMN is bound more tightly than the reduced form. The observed properties of native Old Yellow Enzyme, as well as those of enzyme reconstituted with artificial flavins, might be explained by the existence of a positively charged protein residue in the vicinity of the flavin 6-position. This residue could be responsible for the strong binding of phenolates and various anions (Massey \& Schopfer, 1986). It could also be the 
protein residue that becomes covalently attached to the flavin on light irradiation of the 6- $\mathrm{N}_{3}-\mathrm{FMN}$ enzyme (Massey et al., 1986). A protein base so positioned could posibly interact with the sulfenate species II of Scheme II and, in doing so, stabilize it against further oxidation.

\section{REFERENCES}

Becvar, J., \& Palmer, G. (1982) J. Biol. Chem. 257, 5607-5617.

Biemann, M., Claiborne, A., Ghisla, S., Massey, V., \& Hemmerich, P. (1983) J. Biol. Chem. 258, 5440-5448.

Blankenhorn, G., Osuga, D. T., Lee, H. S., \& Feeney, R. E. (1975) Biochim. Biophys. Acta 386, 470-478.

Burnett, R. M., Darling, G. D., Kendall, D. S., LeQuesne, M., Mayhew, S. G., Smith, W. W., \& Ludwig, M. L. (1974) J. Biol. Chem. 249, 4383-4392.

Choi, J.-D., \& McCormick, D. B. (1980) Arch. Biochem. Biophys. 204, 41-51.

Claiborne, A., Massey, V., Fitzpatrick, P. F., \& Schopfer, L. M. (1982) J. Biol. Chem. 257, 174-182.

Fitzpatrick, P. F., \& Massey, V. (1983) J. Biol. Chem. 258, 9700-9705.

Fonda, M. L., \& Anderson, B. M. (1969) J. Biol. Chem. 244, 666-674.

Ghisla, S., \& Mayhew, S. G. (1976) Eur. J. Biochem. 63, 373-390.

Ghisla, S., Mayhew, S. G., \& Massey, V. (1976) in Flavins and Flavoproteins (Singer, T. P., Ed.) pp 334-340, Elsevier, Amsterdam.

Ghisla, S., Kenney, W. C., Knappe, W. R., McIntire, W., \& Singer, T. P. (1980) Biochemistry 19, 2537-2544.

Ghisla, S., Massey, V., \& Yagi, K. (1986) Biochemistry 25, 3282-3289.

Hellermann, L., Coffee, D. S., \& Neims, A. H. (1975) J. Biol. Chem. 240, 290-298.

Massey, V. (1980) in Photoreception and Sensory Transduction in Aneural Organisms (Lenci, F., \& Colombetti, G., Eds.) pp 253-269, Plenum, Oxford.

Massey, V., \& Hemmerich, P. (1982) in Flavins and Flavoproteins (Massey, V., \& Williams, C. H., Eds.) pp 83-96,
Elsevier/North-Holland, New York.

Massey, V., \& Ghisla, S. (1983) 34th Mosbach Colloquium (Sund, H., \& Ullrich, V., Eds.) pp 114-139, SpringerVerlag, Berlin.

Massey, V., \& Schopfer, L. M. (1986) J. Biol. Chem. 261, 1215-1222.

Massey, V., Müller, F., Feldberg, R., Schuman, M., Sullivan, P. A., Howell, L. G., Matthews, R. G., \& Foust, G. P. (1969) J. Biol. Chem. 244, 3999-4006.

Massey, V., Ghisla, S., \& Moore, E. G. (1979) J. Biol. Chem. 254, 9640-9650.

Massey, V., Claiborne, A., Biemann, M., \& Ghisla, S. (1984) J. Biol. Chem. 259, 9667-9678.

Massey, V., Ghisla, S., \& Yagi, K. (1986) Biochemistry (preceding paper in this issue).

Mayhew, S. G. (1971) Biochim. Biophys. Acta 235, 289-302.

Mayhew, S. G., Whitfield, C. D., Ghisla, S., \& Jorns, M. (1974) Eur. J. Biochem. 44, 579-591.

Moore, E. G., Ghisla,S., \& Massey, V. (1979) J. Biol. Chem. 254, 8173-8178.

Pryor, W. A., \& Castle, L. (1984) Methods Enzymol. 105, 293-299.

Schopfer, L. M., Massey, V., \& Claiborne, A. (1981) J. Biol. Chem. 256, 7329-7337.

Smith, D. J., Maggio, E. T., \& Kenyon, G. L. (1975) Biochemistry 14, 766-771.

Smith, W. W., Burnett, R. M., Darling, G. D., \& Ludwig, M. L. (1977) J. Mol. Biol. 117, 195-225.

Stankovich, M., \& Fox, B. (1983) Biochemistry 22, 4466-4472.

Steenkamp, D. J., McIntire, W., \& Kenney, W. C. (1978) J. Biol. Chem. 253, 2818-2824.

Stewart, R. C., \& Massey, V. (1985) J. Biol. Chem. 260, 13639-13647.

Sullivan, P. A., Choong, Y. S., Schreurs, W. G., Cutfield, J. F., \& Shepherd, N. G. (1977) Biochem. J. 165, 375-383.

Van den Berghe-Snorek, S., \& Stankovich, M. T. (1985) $J$. Biol. Chem. 260, 3373-3379.

Yagi, K., Kondo, N., Ohkawa, H., \& Ohishi, N. (1980) Biochem. Int. 1, 245-252. 